
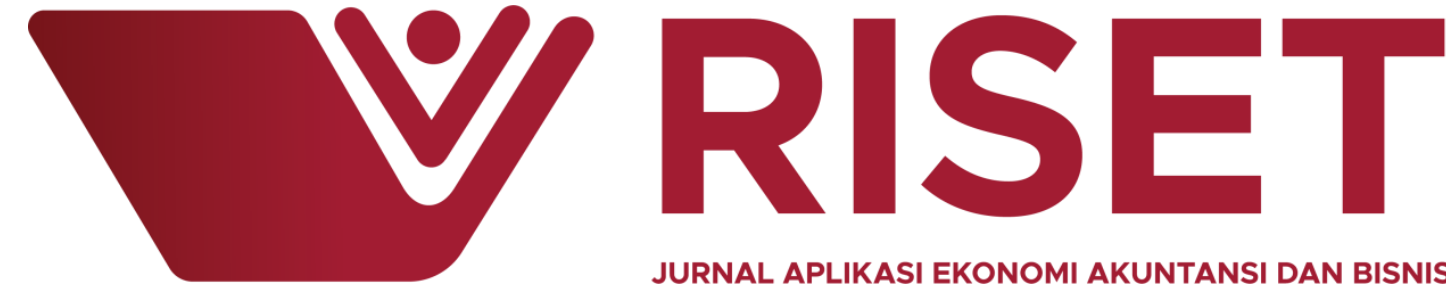

JURNAL APLIKASI EKONOMI AKUNTANSI DAN BISNIS

\title{
CASE ANALYSIS OF REVENUE RECOGNITION FRAUD OF PT GARUDA INDONESIA (PERSERO) Tbk IN 2018
}

\author{
Made Hari Prayoga ${ }^{1)}$, Dyah Purwanti ${ }^{2)}$ \\ ${ }^{1), 2)}$ Politeknik K euangan Negara (PKN) STAN
}

\section{INFO ARTICLES}

Case Analysis Of Revenue Recognition Fraud Of Pt Garuda Indonesia (Persero) Tbk In 2018

Submitted:

29 - Agustus - 2020

Revised:

23 - September - 2020

Accepted:

25 - September - 2020

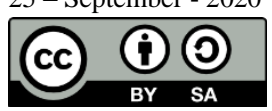

\begin{abstract}
The purpose of this study is to analyze cases of revenue recognition fraud at PT Garuda Indonesia that occurred for the 2018 financial statements. This case attracted public attention because PT Garuda, one of the leading stateowned airlines in Indonesia, is known for its service performance. To achieve our research objectives, we investigated these fraud cases with a qualitative approach. The study's findings are that PT Garuda Indonesia committed fraud by acknowledging compensation income to install connectivity and entertainment service equipment onboard. Also, for content management from the agreement with PT Mahata Aero Teknologi consolidated financial statements of PT Garuda Indonesia (Persero) Tbk in 2018. Action This is intent or negligence and is included in the cook the book scheme, namely recognizing income before it can be identified. Fraud is driven by industrial pressures in the form of unfavorable industrial conditions and financial pressures. Companies try to book maximum profits to achieve the target set. The result of the action is that the resulting financial statements are materially misleading.
\end{abstract}

Keywords: fraud, revenue recognition, PT Garuda Indonesia

\section{INTRODUCTION}

The growth of the air transportation sector has made mobility between regions even higher. The increase in available flight routes indicates an increase in mobility. Based on the air transportation statistics for 2018 from the Central Statistics Agency (BPS), the number of passenger arrivals and departures from 2014 to 2018 has always increased. It is supported by advances in information technology that make it easier for users of this transportation mode to order airplane tickets. Even consumers can make purchases long before the date of departure with various payment facilities. Based on CNBC Indonesia data, online ticket booking is a segment of the travel service industry that has grown more than $40 \%$. Tiket.com CEO, George Hendrata, said that booking airline and hotel tickets still dominates its performance. Tiket.com is the second-largest online ticket booking with an application-based provider company in Indonesia. The ticket sales cooperation scheme between airline companies and online ticket booking application providers also has its revenue recognition characteristics.

The increase in flight routes also helped the logistics distribution quickly by air. High value and time-sensitive shipping of goods are highly dependent on air freight. Statistic air transport by 2018, the number of cargo carriers still have a trend that is 
likely to increase from year to year (CBS, 2018). Ticket sales and cargo delivery are the primary source of revenue for airlines. Other payments, such as revenue from advertising services, ground handling services, temporary stockpiles, and others, constitute additional revenue.

During this mobility development, it turns out that airline companies have a declining revenue trend from year to year. PT Garuda Indonesia (Persero) Tbk. One of the company in Indonesia with a market share of freight domestic $75 \%$ market share of scheduled flights domestic $33.23 \%$, and a market share of flying international routes, $36.23 \%$ in 2018 , posted a net profit of US \$ 77.9 million in 2015, US \$ 9.4 million in 2016, and a net loss of US \$ 213.4 million in 2017. These statistics show that the air transportation industry's development is not directly proportional to company performance when viewed from net income.

In the 2018 consolidated financial statements of PT Garuda Indonesia (Persero) Tbk. gave a surprise by reporting profits after the previous three years continued to show a decline in profits. But the gains recorded are debated because many parties, including the two Commissioners company, believe that there is no corresponding revenue recognition, which led the top company to record profits. The polemic led to the stipulation of fraud by PT Garuda Indonesia (Persero) Tbk. PT Garuda Indonesia (Persero) Tbk was determined to have committed fraud in recognition of compensation income for the right to install connectivity and entertainment service equipment onboard and content management originating from a contract with PT Mahata Aero Teknologi.

Three Indonesian state institutions found out that there was a fraud exist. The institutions include; the Financial Services Authority (OJK), the Center for Financial Professional Development (PPPK) of the Ministry of Finance of the Republic of Indonesia, and the Supreme Audit Agency of the Republic of Indonesia (BPK-RI) found out that there is a fraud occurred. The fraud exists in presenting the consolidated financial statements of PT Garuda Indonesia (Persero) Tbk. 2018, namely the recognition of compensation income for the right to install connectivity and entertainment service equipment in aircraft and content management for the cooperation agreement with PT Mahata Aero Teknologi, which does not follow accounting standards. Sanctions have imposed on the directors and commissioners of PT Garuda Indonesia (Persero) Tbk and a public accountant's office to audit the Office of Public Accountant (KAP) Tanubrata, Sutanto, Fahmi, Bambang \& Partners.

According to Romney (2015), three factors contribute to fraud is the pressure, opportunity, and justification (rationalization). These three factors are referred to as the fraud triangle. Financial reporting pressure for directors to show adequate economic performance and achieve expected revenue targets is one of the driving factors for fraud in financial reporting. Companies that experience a decrease in profits each year are under pressure to be able to show increased performance and eventually commit fraud. It is related to the airline's business income's unique characteristics and the existence of fraudulent practices in recognizing airline company earnings. For researchers, this topic is exciting to study, to analyze the income accounting treatment of PT Garuda Indonesia (Persero) Tbk first, to provide a basic understanding for reviewing the revenue recognition fraud cases that have occurred.

\section{LITERATURE REVIEW}

\section{Income Recognition}

In PSAK 23, it is explained that income is the gross inflow of economic benefits arising from the company's ordinary activities during a period when the inflow results in an increase in equity, which does not come from the contribution of investors. Besides, PSAK 23 also regulates that income is recognized when it is probable that future 
economic benefits will flow to the company, and these benefits can be measured reliably. The recognition criteria are usually applied separately to each transaction. However, it is necessary to use the recognition criteria to individually identifiable components of a single transaction to reflect the transaction's substance in some circumstances.

The statements in PSAK 23 should apply in accounting for income arising from the following economic transactions and events: (1) sale of goods; (2) sales of services; and (3) use of company assets by other parties that generate interest, royalties, and dividends. Sales of goods include goods that the company produces for sale and items purchased for resales, such as merchandise bought by retailers or land and other property purchased for resale. Sales of services usually involve carrying out tasks that have been contractually agreed to be carried out during a period decided by the company. The service can be delivered for one period or more than one period. Some sales service contracts arising from construction contracts, such as sales service contracts concerning project managers and architects, are not discussed in this statement.

The use of company assets by other parties generates income in the form of:

1. Interest - charges for the benefit of cash or cash equivalents or the amount owed to the company;

2. Royalties - charges for the long-term use of the company's assets, for example, patents, trademarks, copyrights, and computer software; and

3. Dividends - distribution of profits to equity investment holders according to their proportion of the particular type of capital.

Fraud

According to Romney (2015), someone uses fraud to get an unfair advantage from others. By law, an action considered as fraud must fulfill:

- incorrect reports, representations, or disclosures

- material fact, which is something that prompts a person to act

- intention to cheat

- justifiable reasons; that is, things that relied on as justification for committing an act of fraud

- injury or loss suffered by the victim.

There are two categories of fraud: asset misappropriation (Misappropriation of Assets), called employee fraud, financial reporting fraudulent, or so-called fraud management. Misuse of assets is an act of theft of company assets by employees. Fraudulent financial reporting is an intentional act or negligence, either by acting or neglect, which results in materially misleading financial reports. Management fakes financial statements to deceive investors and creditors, increase the company's stock price, meet cash flow needs, or hide its losses and problems. The most common scheme is to cook the book, which includes fictitious increases in income, recognizing income before it earned, deferring current expenses to the next period, overestimating inventories or fixed assets, and hiding losses liabilities.

Albrecht .W.Steve (2002) in Amrizal (2004) explains that one type of fraud is management fraud. This type of fraud is characterized by top-level management. The perpetrator usually misrepresents the information in the financial statements, and users of financial statements, including investors, become victims who obtain misleading information. 


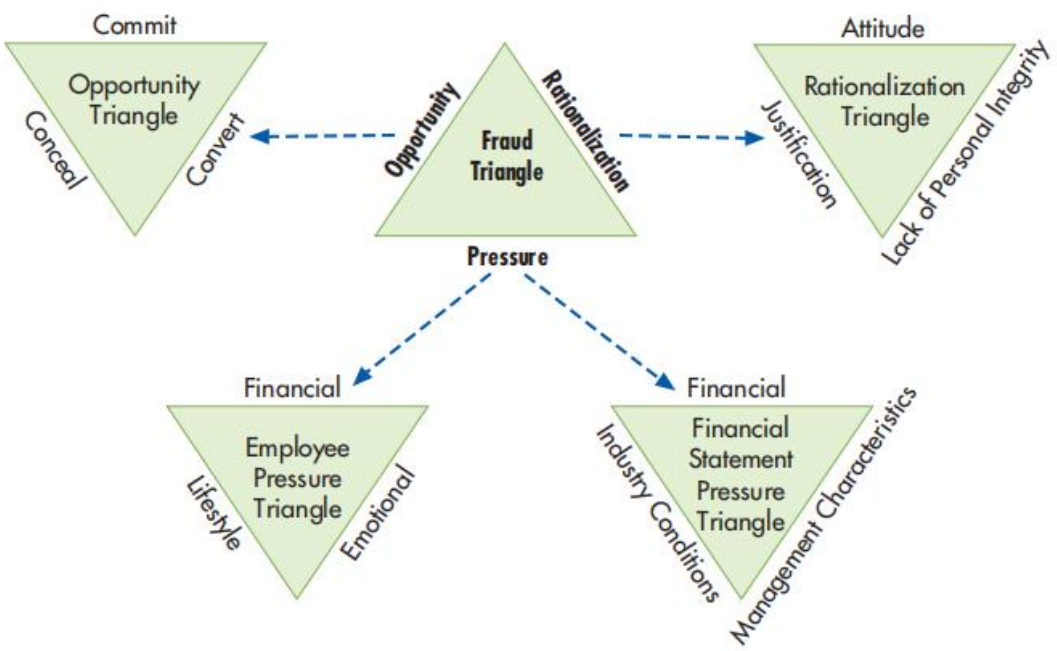

Source: Romney (2015)

Figure 1. Fraud triangle

Fraud triangle is a triangle which illustrates the three factors that drive an act of fraud. Three of these factors are the chance (opportunity), justification (rationalization), and pressure. Options are conditions or situations, including a person's abilities, that allow the perpetrator to commit, hide, and change the fraud. Rationalization will enable offenders to justify their illegal behavior. The shape of rationalization divided into three: justification (justification: "I just took what was owed them to me"), an attitude (attitude: "The rules do not apply to me"), and the lack of personal integrity (lack of personal integrity: "Get what I want is more important than being honest ").

The pressure is an incentive or motivation for someone to commit fraud. The force that drives the scam may be caused by employee financial stress and anxiety of the financial statements. The financial pressures often motivate fraud committed by the employee, for example, emotional factors such as greed, ego, pride, and desire against the system, lifestyle factors, and financial factors. Pressure for the organization's financial statements or force that motivates management to present the financial statements is incorrect.

Financial reporting pressures consist of pressure on management characteristics, industry conditions, and economic forces.

a. Management Characteristics

1. Questionable management ethics, management style, and track record

2. Overly aggressive income forecasts, performance standards, accounting methods, or incentive programs

3. Significant incentive compensation based on excessively aggressive achievement of life goals

4. Management actions or transactions without a clear business justification

5. Excessive sensitivity to the effects of changing the original accounting treatment on earnings per share

6. A strained relationship with the auditor's past

7. Failing to correct errors in time leads to even more significant problems

8. High management/employee turnover

9. Related parties are unusual/odd relationship

b. Industrial Conditions

1. Industry is in decline

2. Industrial or technological changes that lead to decreased demand or product obsolescence

3. New regulatory requirements that disrupt financial stability or profitability 
4. Significant competition or market saturation, with reduced margins

5. Significant tax changes or adjustments

c. Finance

1. Strong pressure to meet or exceed income expectations

2. Significant cash flow problems; difficulty collecting accounts receivable and paying off debts

3. Large losses, high or undiversified risk, increased dependence on debt, or debt covenants that are too restrictive

4. Strong reliance on new or unproven products

5. Outdated inventory or excessive build-up of supplies

6. Economic conditions (inflation, recession)

7. Litigation, especially management vs. shareholders

8. Business failure or impending bankruptcy

9. Problems with regulatory agencies

10. High vulnerability to raise interest rates

11. Poor or deteriorating financial position

12. Growth or profitability is unusually fast compared to companies in the same industry

13. Significant estimates that involve highly subjective judgments or uncertainties

\section{METHODOLOGY}

This research uses a descriptive qualitative approach. The data source using financial statement data PT Garuda Indonesia in 2014-2018, information related to fraud Garuda cases from news sources online, documents PT Garuda published contract, and other regulatory $\mathrm{n}$ huh relevant. Then analyze with a review of these documents then describe one by one the discussion with the related literature.

Qualitative research is aimed at obtaining a basic understanding through direct observation through the experience of researchers who directly process and merge into one with the subject and background to be studied in the form of real, real reports and actual field notes (Denzin \& Lincoln, 1994, in Herdiansyah, 2010). The scope of this research is to observe cases of fraud related to revenue recognition. PT Garuda Indonesia is presented in the financial statements of the year 2018.

\section{RESEARCH RESULTS}

In part, this will be analyzed regarding fraud carried out by PT Garuda Indonesia to the recognition of income in the financial statements of 2018. The revenue in question is heading. Other payment in the form of income compensation for the proper installation of equipment and connectivity services in-flight entertainment and content management amounted to USD.239,940,000 from the agreement made with PT Mahata Aero Teknologi. The company has not received compensation from the contract, so it is still recorded in the other accounts receivable.

a. Background of Fraud

Romney (2015) stated that the driving force for fraud in financial reporting consists of pressure, opportunity, and rationalization. One of the main discussions is the existence of financial reporting pressure for directors regarding its financial performance. As seen in the company's operating profit (loss) graph and net profit (loss), the company has compactly decreased from 2015 to 2017 for three consecutive years. Even back to experience losses of up to USD. 213,389,678 in the year 2017 after the latter suffered a loss in the year 2014. In the year 2018, the company recorded 
operating segment results low of USD.45.18 million, decreased by $65.11 \%$ compared to 2017 amounting to USD.129.50 million. The aviation operation segment is the company's main segment, accounting for $87.01 \%$ of its total operating revenue. This change was caused by an increase in operating expenses such as aircraft fuel costs, airport, and air navigation cost, and the large amount of other operational costs that arose during natural disasters in several cities in Indonesia during 2018, which were also exacerbated by the depreciation of the rupiah. An increase in expenses by $9.05 \%$ was only followed by an increase in $6.46 \%$ revenue, which resulted in a significant decrease in this segment's results.

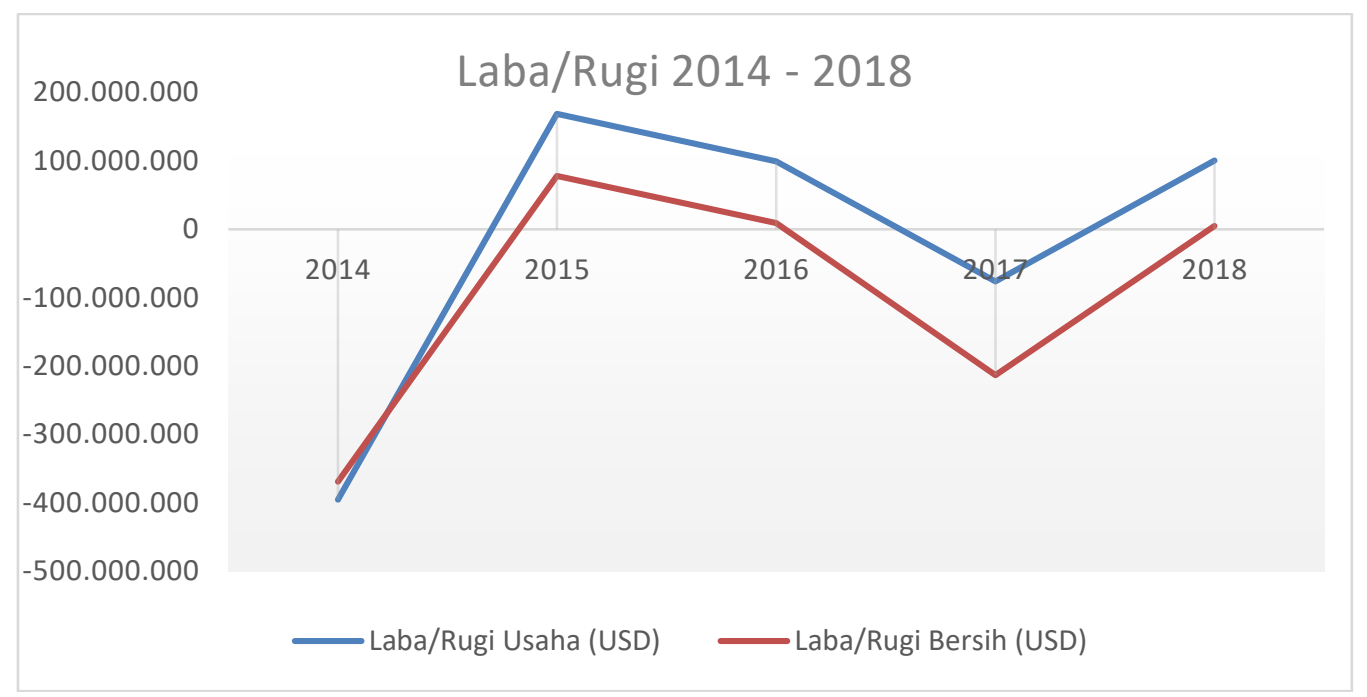

Figure 2. Statistic of Company profit (loss) in 2014-2018

Processed from: Financial reports of PT Garuda Indonesia (www.idx.co.id)

As shown in table 1, 2018 can be seen as the company averaging target operating income, assets, and liabilities above $60 \%$. Net profit and net profit margin have not demonstrated satisfactory achievement targets in 2018, namely only $16.72 \%$, and $18.93 \%$. Again, this was caused by a very significant increase in operating costs, especially aircraft fuel, which was also exacerbated by the rupiah's depreciation. In 2018 , jet fuel's average price increased significantly by $20.04 \%$ than in 2017 , while the rupiah currency also depreciated by $6.62 \%$ compared to 2017 . Besides, the high price competition in the domestic market and international also significantly affect its financial performance.

Following this illustration, it is seen that unfavorable industry conditions put pressure on the board of directors and could be one of the driving factors for revenue recognition fraud. PT Garuda Indonesia is a state-owned company (BUMN). Two of the five objectives of its establishment are contributing to the development of the national economy in general and state revenue in particular and pursuing profits, as stated in Law Number 19 of 2003 concerning Owned Enterprises Country. According to this, directors must show adequate financial performance by increasing revenue and minimizing costs to achieve maximum profit. Efforts to increase profits that must be earned amid the deteriorating industrial situation will certainly pressure management. 
Table 1 Performance Financial 2018

\begin{tabular}{lccc}
\multicolumn{1}{c}{ Description } & $\begin{array}{c}\text { Realization } \\
\text { (USD billion) }\end{array}$ & $\begin{array}{c}\text { RKAP * } \\
\text { (USD billion) }\end{array}$ & $\begin{array}{c}\text { Achievement } \\
(\%)\end{array}$ \\
Operating revenues & 4.37 & 4.95 & 88.32 \\
Net Profit / (Loss) & 5.02 & 30.03 & 16.72 \\
Net Profit (Loss) Margin & 0.10 & 0.61 & 18.93 \\
Minimum Cash & 5.76 & 10.10 & 57.03 \\
Asset & 4.37 & 5.35 & 81.73 \\
Liabilities & 3.46 & 4.20 & 82.33 \\
Equity & 0.91 & 1.14 & 79.55 \\
\hline
\end{tabular}

* RKAP: Work Plan and Company Budget

Processed from: PT Garuda Indonesia annual report ( www.idx.co.id )

The impact of fraud in revenue recognition has improved the company's performance. It has seen an increase in the company's operating profit and net profit from the previous year. The declining industry's impact due to increasing fuel prices, depreciation of the rupiah, and high price competition are eliminated by recognizing other income outside its main business. This other income is in the form of compensation income for installation rights for in-flight entertainment and connectivity services equipment and content management amounting to USD.239,940,000. It is not wrong that recognizing this income is considered the savior of Garuda's financial performance at the end of 2018.

Up by Quarter III year 2018, the company still suffered a loss of USD. $110,231,730$. However, at the end of the year 2018, the company managed to earn a profit of USD.5,018,308 or a change of $102.35 \%$ compared to the previous year after recognizing revenue from contracts with Mahata. If without such revenue recognition, the company will experience an operating loss of USD.139,260,766 and a net loss of USD.175,028,261. The operating loss increased compared to an operating loss experienced in 2017, as shown in figure 3. The graph data is data earnings (loss) based on the company's consolidated statements of 2018 restated. The listed company's net loss in 2018 amounted to $583.16 \%$ below its target set.

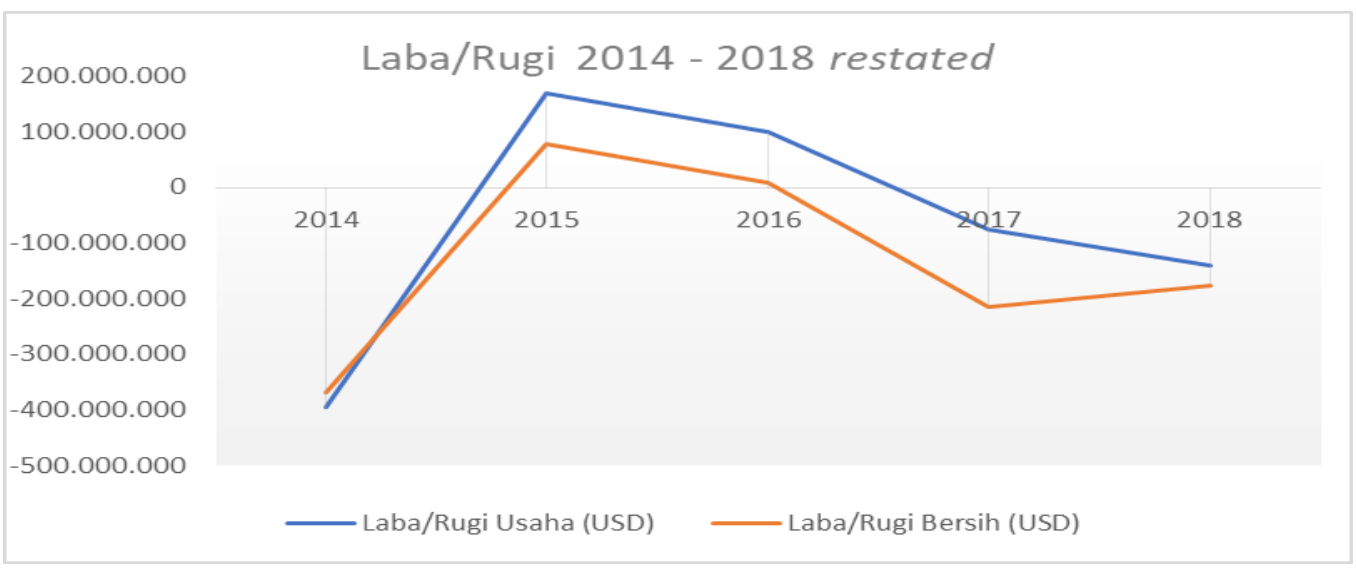

Figure 3 Statistic of Company profit (loss) in 2014-2018 ( restated)

Processed from: Financial reports of PT Garuda Indonesia ( www.idx.co.id ) 
b. Contract Identification other income in the form of compensation income for installing connectivity and entertainment service equipment in the aircraft and content management. It comes from the contract number CITILINK / JKTDSQG / PERJ6248/1018 dated 31 October 2018, which was last amended in amendment II number CITILINK / JKTDSQG / AMAND- II / 6248/1218 dated 26 December 2018. These worked together to install equipment and connectivity services, in-flight entertainment, and content management by PT Mahata Aero technology that involves aircraft operated by Garuda, Citilink, and Sriwijaya.

1) The parties

The provider of in-flight connectivity and entertainment services and content management in the agreement is PT Mahata Aero Teknologi. Meanwhile, service recipients include PT Garuda Indonesia, PT Citilink Indonesia, and PT Sriwijaya Air. The President Director of Citilink, signed the cooperation agreement.

2) Performance Obligation (job obligations)

To obtain the company revenue, it is obliged to provide installation rights for connectivity service equipment and management rights for inflight entertainment services and content management. In public Expose Incidentally related cooperation of Garuda Indonesia Group - Mahata Aero Technology, revealed that the obligations of Garuda Indonesia are:

According to the Aircraft List Service (ALS, providing aircraft) includes arranging the lessor's equipment installation permit if the plane is a chartered aircraft.

- The aircraft in ALS can be replaced with other aircraft that are not installed.

- Notify Mahata in writing if the corresponding aircraft lease period ends before the end of the period or the connected aircraft is no longer operational.

- Responsible for any damage to the connectivity service equipment if caused by Citilink officers at Citilink's fees.

- Take part in maintaining and maintaining that all connectivity service equipment belonging to Mahata is always in good condition and can be operated in good condition

- Give the best effort to help Mahata obtain the necessary permits in this collaboration.

Meanwhile, the obligations of Mahata Aero Teknologi, as stated in the document are:

- Carry out and cover all costs of supply, implementation, installation, operation, maintenance, and dismantling and maintenance.

- Provide and assign competent and certified personnel for the equipment.

- Guarantee and be responsible for any aircraft damage related to installation.

- Guarantee and liable for all return condition costs.

- Provides In-Flight Connectivity Services on the aircraft following the In-Flight Connectivity Services operating schedule of each plane according to the installation schedule

- Obtain and maintain all licensing and certification of equipment, service, connectivity, and personnel

3) The term of the contract

Under the second amendment has been done, contracts the same is valid for 15 years. Mahata has the right to install connectivity services equipment and management rights for in-flight entertainment and content management services for 15 years.

4) Value of income

The income value is USD.239,940,000 can be identified from the contract as follows: 
a. USD worth of compensation. 39,000,000 for the rights of installing equipment in-flight connectivity service on 50 aircraft of type A320 series operated by Citilink.

b. USD worth of compensation. $92,940,000$ for the rights of installing equipment in-flight connectivity service on 20 aircraft of type A330 series, 73 aircraft of type B737-800 NG and 10 B777 type aircraft operated by Garuda.

c. USD worth of compensation. 80,000,000 for in-flight entertainment services and content management rights for 18 A330 aircraft, 70 Boeing 737-800 NG aircraft, 1 Boeing 737-800 MAX aircraft, and 10 Boeing 777 aircraft.

d. Incentives for companies worth USD.28,000,000 as compensation for Sriwijaya's participation in the in-flight connectivity service agreement between the Company and Mahata.

In addition to the income, it is taken from the compensation. The company is also entitled to income in the form of annual slot allocation payments since the inaugural flight. While, for the actual income earned by Mahata's efforts amounting to 5\% of the total substantial revenue in year 1 , amounting to $6 \%$ of the total substantial income in 2nd of 7, $5 \%$ of total actual revenue in year 3 to year 10 for each ad that is obtained by Garuda. For advertisements received by Mahata, Mahata is obliged to pay slot allocation to the Group annually since the inaugural flight, for the actual revenue earned by the Group's efforts amounting to $95 \%$ of the total substantial revenue in year 1 of $94 \%$ of the total actual revenue in year 1. -2 in the amount of $92.5 \%$ of the entire real income in years 3 to 10 . The slot allocation pattern for years 11 to 15 has not been determined.

c. Fraud Identification

Several things can indicate and evidence of fraud in revenue recognition, including contracts that are not by the provisions, income recognition errors, and potential conflicts of interest. In this discussion, the writer will discuss the revenue recognition error and the non-conforming contract issue because the contract mismatch condition supports the revenue recognition error. Contracts that are not following the provisions and potential conflicts of interest prevent revenue from being recognized following accounting standards and make it an act of fraud. The three factors are described as follows.

I) Work at providing connectivity services and in-flight entertainment with PT Mahata Aero Technology is not following provisions.

The results of the BPK examination revealed that the agreement made was not following existing regulations. Directors Garuda and Directors Citilink are not guided by the Regulation of the Minister of SOE No. Per-03 / MBU / 08/2017, as already amended by Regulation of the Minister of SOE No. Per-04 / MBU / 09/2017 on p Guidelines for k Gov s ama SOEs which stipulates that in looking for a partner to do based SOP which is set by the Board of Directors and pay attention to the principles, transparency, independence, accountability, responsibility, benefit, and fairness, and following the provisions of law. The agreement is also not following the Civil Code at $\mathrm{p}$ origin 1320, which regulates the validity of a contract and Article 1335, which explains the conditions in which the contract will not have legal force. The discrepancies that occur are as described below.

a) The selection of partners is not following the provisions.

The mismatch includes, first Mahata electoral process as a partner of the same. It is known that the Garuda Citilink and yet have SOPs that set about working together at the time of the agreement with Mahata made. Without the use of guidelines, Mahata designated as directly as partners working together without any comparison and is not 
supported by studies on partners working together technically and financially adequate. After the BPK conducts an inspection, it is known that:

1. Mahata not feasible in terms of technology designated as partners working together.

It is because Mahata is a start-up company that was just established and was only legal on 8 November 2017. Thus, at the time of declaration of interest and approval, work together with delivered by Mahata by mail to Citilink dated 19 October 2017 of the Letter of Interest and Consent Work the Same Wi-Fi in aircraft Citilink, Mahata still has not become a body of law.

Due to technical inability, Mahata cooperates with Lufthansa Technic, Lufthansa System, Inmarsat, and CBN, which provide assistance and supervision to Mahata in installing connectivity services. However, this agreement has not been made at the time of the signing of the Statement of Interest in Joint (MoU) on Cooperation Installation and Operating Facility Wireless Network Connection ( $\mathrm{Wi}-\mathrm{Fi}$ ) in the aircraft Citilink at 15 November 2017.

Mahata with Lufthansa Technic and Lufthansa Systems recently signed on 8 June 2018, with the new Inmarsat signed on 11 July 2018, and with the new CBN was signed on 24 October 2018.

- Before the agreement works together between Citilink and Mahata, Mahata did not have permission from the Ministry of Communication and Information. Mahata is not certified for installing aviation connectivity equipment and does not have personnel who have the experience, qualifications, and certification to install commercial aircraft equipment. So to the installation of equipment Wi-Fi, Mahata does work together with Garuda Maintenance Facility (GMF) related to installation only by purchase order (PO). Yet, there is a contract that is agreed between Mahata and GMF. Then on 23 April 2019, the Mahata and GMF signed a proposal to perform GXAviation Installation on Citilink Year 2019 with No. GMF / TP / PROP2060/19. Installation of connectivity equipment was carried out by technicians provided by GMF with supervision from Lufthansa Technic.

Mahata also does not have any additional equipment installation certification. The new Lufthansa Technic is licensed by the European Aviation Safety Agency (EASA), an agency responsible for ensuring air transportation safety and environmental protection in the European region, for installation on A330-200 type aircraft. Meanwhile, for the installation permit on Boeing aircraft, the licensing process is still being carried out by the Federal Aviation Administration (FAA), the United States civil aviation regulatory agency. It takes approximately six months and is expected to be completed in September 2019.

2. Mahata does not have the financial capacity to cooperate.

Mahata has an authorized capital of Rp. 10,500,000,000, while the value of cooperation with Garuda, Citilink, and Sriwijaya reaches USD. 241 , 940,000 . Thus, the working agreement's value together far exceeds the value of the assets that can not be used as collateral for the value of cooperation with Garuda Citilink and Sriwijaya.

To mitigate the financial inability owned, Mahata signed an agreement together with the Well Vintage Enterprises as a provider of capital ( financial support ) on 28 February 2019 or after the signing of the contract work together with Citilink. As a new company Mahata does not publish reports of financial for the year 2017 and 2018. As of the end of the examination is known that Mahata still pulls through the reporting process of economic.

b) The cooperation agreement is not following the provisions.

Agreement between Citilink with Mahata not following the provisions. Because it does not qualify the validity of a contract, the deal is not yet final, the amount of 
compensation that can not be specified and measured, and an additional term of the agreement, which does not add to the payment cost.

1) The cooperation agreement between Citilink and Mahata does not meet the agreement's legal requirements, especially on the parties' position and the object of the contract. It is evident in agreement number Citilink / JKTDSOG / PERJ$6248 / 1018$, together with all amendments. It is written that the Director of Citilink is only acting for and on behalf of the company that is Citilink, and stated that the Director of Citilink gets power from Garuda or Sriwijaya so that tying themselves in the cooperation agreement this is only Citilink side with Mahata. Therefore, Garuda and Sriwijaya do not have a legal position, including not having rights and obligations in the Cooperation Agreement for the Provision of Connectivity Services in Flight CITILINK / JKTDSQG / PERJ-6248/1018. Agreement work together providing service connectivity in flight is an agreement between Mahata with Citilink. However, the object of the deal is not only Citilink aircraft but also Garuda and Sriwijaya aircraft. Also, in a power of attorney, the President Director of Sriwijaya gave authority over 50 aircraft consisting of 47 aircraft owned and three aircraft, which were still in agreement and not yet owned by Sriwijaya. The pledge of goods belonging to the others who did not participate becomes party to a treaty means that the agreement's object does not meet the requirements because that is kosher. Citilink, bound by the agreement, does not have authority over a number of objects of the agreement, which is against the law.

2) The cooperation agreement is declared not yet final because the appendix will still be made to regulate details regarding the rights and obligations of Garuda and Sriwijaya, implementation guarantees and late fees, implementation and payment mechanisms, and slot allocation or profit-sharing for years 11 to years 15th. President Director Mahata and Commercial Director Citilink stated that there are still many clauses that need to be discussed, especially regarding the payment of compensation costs. Although two appendices have been made, until the end of the audit by the BPK, no further regulations have been found regarding implementation guarantees, slot allocation revenue guarantees, and late fees. The amendment with cooperation agreement as outlined in Addendum II, one of which is regarding the additional period of the cooperation agreement from 10 years to 15 years, but the supplement does not yet regulate the amount of slot allocation paid by Mahata in the 11 th to 15 th years. The number of things that have not been held means that the agreement cannot be considered final. The possibility of the appendix also does not preclude changing the amount of revenue recognized as happened in the previous two addendums.

3) Compensation fee of USD. Two hundred thirty-nine million nine hundred forty thousand cannot be elaborated and without study. Compensation Cost installation rights and management rights IFE services stated in the agreement constitute a submitted Mahata through Citilink and approved by the Garuda. However, Garuda, Citilink, and Sriwijaya did not know the details of the calculation or formula for determining the cost of compensation for rights agreed in the agreement and did not conduct a study to determine the appropriate value cooperation. President Director Mahata stated that the compensation fee submission considers the number of planes and/or passengers' numbers. Still, a working paper does not support it for calculating the compensation costs.

4) The additional period does not increase the number of compensation costs. Addendum II add period working together than ten years became 15 years but is no addition to the magnitude of the price of compensation paid to Mahata to Garuda, Citilink, and Sriwijaya. 
Under the agreement discrepancy has been discussed, the general impact is Mahata not able to carry out most of the scope of work in the employment agreement together. Mahata was also unable to pay the USD compensation fee. 239. 940. 000 following the deadline specified in the invoice, the status cooperation agreement between Garuda and Sriwijaya with Mahata unclear and potentially does not have the force of law. The risk operations to be faced Garuda, Citilink, and Sriwijaya in implementing the cooperation agreement together. BPK recommends the Minister of State, Directors Garuda, and Directors Citilink to cancel the Agreement Work Same Provision of Services Connectivity and IFE year 2018 with Mahata, and executed referring to the provisions of law.

II) The recognition of income does not follow the statement of financial accounting standards (PSAK) 23 concerning the payment.

Three state institutions checked the financial statements company in 2018 that the Financial Services Authority. Where the Ministry of Finance, and the State Audit Boar, hase determined that its revenue recognition on contracts and PT Mahata Aero Technology does not conform with financial accounting standards. Companies using Standard Statement In militancy Finance (IAS) 23 in cooperation with the transaction, treat Mahata, namely as the sale of goods or the use of assets by the other party who raises the royalty, so the company recognizes the total income compensation that amounted to USD. 239,940,000 int cope 2018. Basic recognition of revenue as a whole in tear 2018 is used by company.

1. In the agreement working together that has been signed, Mahata agreeing to pay compensation to the Garuda Citilink and Sriwijaya after signed its partnership agreement;

2. Citilink will be evaluated every two months the implementation of the contract of work together, and if the results of the evaluation showed that the agreement work together is not profitable, or in the case Mahata not carry out the obligations and responsibilities he said, Citilink has the right to terminate the deal work together, and all the rights and obligations that have not been completed and/or has arisen as a result of the application of the cooperation agreement and must be completed not later than 14 days after the cooperation agreement ends;

3. Insubstantial rewards were received on delivery of the right of installation, and management rights are at the top of compensation. Fixed or guarantees are not refundable in an irrevocable contract that allows the holder to exploit those rights freely and assign has no remaining obligations to be implemented.

After reviewing the following SFAS 23, it refers to the results of three state agencies. Which also related to doing checks on working agreement together between Citilink with Mahata, the transaction, such as cooperation, does not meet the criteria for using assets by the others who pose a royalty or revenue on sales of goods.

Transactions work together with Mahata not meet the criteria in paragraph 29, which states that the income from the use of assets the entity by parties other generates interest, royalties, and dividends. Which are recognized on the basis described in Paragraph 30 of SFAS 23. It is not to be recognized as revenue on the use of the entity's assets by other parties that generate income in the form of royalties, with the following explanation.

1. There are no intellectual property assets in the form of royalties that are traded. Trade rights for connectivity and in-flight entertainment are not recorded in Garuda's balance sheets and its subsidiaries.

2. It is likely that the economic benefits associated with the transaction will not flow to the entity indicated by Garuda, Citilink, and Sriwijaya that have not received compensation payments from Mahata, and there is no guarantee for the 
compensation payment obligations. Garuda, Citilink, and Sriwijaya have issued invoices due on 31 January 2019, but as of March 2019, there has been no payment. Besides, Mahata only provides a guarantee in the form of a letter that will make payments without an asset guarantee or a bank guarantee to ensure that Mahata will carry out its payment obligations.

3. The amount of revenue cannot be measured reliably because the contract value and the contract scope can change. The scope and value of the contracts in the original contracts and addendum are constantly changing. In the initial contract, the contract value was 79 Garuda aircraft worth USD. 64,140,000 and 75 Citilink aircraft worth USD. Fifty-eight million five hundred thousand in addendum turned into 103 Garuda planes worth USD. 92,940,000, a total of 50 Citilink aircraft worth USD. 39,000,000 and 50 Sriwijaya aircraft worth USD30,000,000, which later in addendum II changed back to 103 aircraft and Garuda in-flight entertainment worth USD. 92,940,000, for 50 Citilink aircraft worth USD. 39,000,000 and 50 Sriwijaya aircraft worth USD. $30,000,000$.

Besides d nature agreements work together, attachment $\mathrm{F}$ number 3 mentioned that for the aircraft operated by Sriwijaya is 50 B737 series aircraft. The provisions will refer to the results of the assessment of Mahata. So that after an evaluation, the value of the agreement can change according to the results of the review. There clausal clauses in employment contracts together and the results confirmed by the CPC indicate that there are likely to be paid compensation costs Mahata may change.

a. Based on the experience Project Manager Mahata, for airplane 737 Classic, equipment installation service connectivity will affect aircraft engines' performance to be investigated more further in order not problematic.

b. President Director Mahata stated that the cooperation agreement's value and the scope of cooperation might change according to the discussion/agreement results between the two parties.

c. Commercial Director Citilink states that the contract with Mahata an umbrella contract where the value and scope are still negotiable, do the review every two months, and do an addendum or termination of the arrangement according to the results the study. Every two months, the examination was conducted to lead negotiations over the value and scope if the deal had not yet provided optimal benefit or harm for Citilink.

d. VP Corporate Secretary \& CSR stated that the existing contract was only a cooperation agreement between Citilink and Mahata. It can be seen from the clause of the agreement work together, which states that the cooperation agreement with Garuda and Sriwijaya will be regulated in a separate agreement or an addendum. However, the Citilink Board of Directors requested that it be legal to include Garuda and Sriwijaya in the contract with a power of attorney from the Garuda Directors and Sriwijaya's attorney's power the President Director of Citilink.

4. In Ilustra the IAS 23, Paragraph 20 stated that the transfer of rights is for a fixed or non-refundable guarantee under a contract. Which can not be canceled that permits the licensee freely to exploit those rights and the licensor has no remaining obligations to be implemented, in substance is a sale. Based on this illustration, the royalty sale transaction is a contract that cannot be canceled. In contrast, Citilink and Mahata connectivity services' cooperation transactions can be canceled where the cooperation agreement clause states that the agreement will be reviewed every two months. A supplement or termination of the agreement can be made in accordance with review results. In the illustration, it is stated that the licensor does not have any remaining obligations to be carried out while in the cooperation transaction for the provision of Citilink and Mahata connectivity services there is still a residual 
obligation from Citilink, namely obtaining permission from the lessor to install connectivity tools. In addition, there is no article in the cooperation agreement clause that states that Mahata is obliged to pay the entire cost of compensation even though the agreement ends before time. Based on the above, cooperation with Mahata transaction does not meet the criteria for par a graph 20 IAS 23 to be recognized as revenue in the form of royalties on the use of assets by the other party completely in 2018 .

Transactions work together with Mahata and not meet the criteria as income on the sale of goods. As mentioned in paragraph 14 of IAS 23, it can not be recognized as revenue on the sale of goods, as described below.

1. There are no physical products traded in the cooperation transaction between Mahata and Citilink.

2. The entity has not transferred the significant risks and rewards of ownership of rights, and Mahata has not fully utilized these rights. Under the agreement work together with providers of service connectivity, Citilink will give the right to Mahata to provide, implement, install, operate, and maintain equipment connectivity services. These also include the in-flight connectivity services to the 50 aircraft operated by Citilink, 103 aircraft operated by Garuda, and inflight connectivity services on Garuda aircraft and 50 aircraft operated by Sriwijaya. The results of the examination show conditions as follows.

a. News Events Serah Thank Right Installation of Equipment Services In-Flight Connectivity, Management Rights IFE Services, and Content Management recently signed by the Director of Citilink on 23 January 2019 when revenue was recognized in 2018. As of 31 December 2018, there is only one connectivity service equipment installed on the aircraft, namely the aircraft operated by Citilink with PK-GQR registration.

b. There are aircraft operated by Garuda, Citilink, and Sriwijaya, which originate from leases to lessors and are included in the cooperation agreement's scope to install connectivity services. The plane that already gets the lessor's permission for a paired tool for connectivity is just as much as nine best of the best 203 plan paired.

c. Aircraft Garuda, Citilink, and Sriwijaya that will be installed is the best type of A320, A330 and B737 series, B737-800NG, B737-800Max, and aircraft B777. Until 31 May 2019, only Airbus A320 aircraft already have a Supplemental Type Certificate (STC) for connectivity, while other aircraft are still being processed.

d. Garuda is even cooperating with the management of in-flight entertainment based on the agreement Number DS / Perj / DC-3266/2014 dated 19 June 2014 with Global Eadle Entertainment Inc (GEE) and Inflight Production Ltd (IFP) until 31 May 2019. When signing the cooperation agreement with Mahata, the promised object was still cooperating with GEE and IFP.

3. The amount of income cannot be measured reliably. The contract value can change if both parties agree on it.

4. likely, the economic benefits associated with the transaction will not flow to the entity because Garuda, Citilink, and Sriwijaya have not received compensation payments from Mahata, and there is no guarantee of the compensation payment obligations.

In addition to not meeting the criteria to be classified as an asset use by parties other that raises royalties or income on the sale of goods, ti n dakan recognize revenue while also not according to accounting standards. Garuda is unable to 
identify all revenue in the income statement at the start of the transaction. Recognition of income at the beginning of a transaction cannot be done with the following explanation.

a. Garuda still has additional obligations that have not been done to provide Mahata access on an ongoing basis over the air are covered in ALS (Aircraft List Service) and the permits to the lessor and the Supplemental Type Certificate (STC).

b. There is significant uncertainty about the collectibility of the benefits. Garuda, up to date a 24 June 2019, has not received a payment, and there is no guarantee that Mahata will carry out its obligations.

c. Recognition of revenue on the transaction work and Mahata entirely in early cooperation agreement is not agreed upon the Committee Audit. The Audit Committee found the cost of compensation for income on cooperation between Citilink and Mahata and can not be fully recognized in 2018. Results from the Study Committee of the Audit to feedback management on Letter BOC No. Garuda / dekom-006/2019 dated 18 February 2019. It was concluded that the explanation, along with supporting documents submitted rule, has not fully endorsed the idea management, which recognizes revenue over the entire cost of compensation rights of connectivity service equipment installation and management of IFE services.

To carelessness, Garuda management recognizes revenue on transaction connectivity and IFE of agreements with Mahata leads to more-food accounts other than USD. 239,940,000 and is serving accounts receivable amounted to USD. 263,934,000 (excluding VAT) to the Consolidated Financial Statements Garuda year 2018, so it has been done with the presentation of financial statements that do not recognize the revenue from these transactions following the CPC's recommendations, the FSA, and the Ministry of Finance.

III) Potential Conflicts of Interest over the Audit of PT Garuda Indonesia Consolidated Financial Statements by KAP

BPK revealed a potential conflict of interest over the audit of the consolidated financial statements of Garuda and its subsidiaries by KAP Tanubrata Sutanto Fahmi Bambang \& Rekan. Results of the investigation of BPK showed there were problems related to the firm on the recognition of revenues on labor transactions equal provision of connectivity services with details as follows.

Garuda management before presenting the work of transactions at the provision of connectivity to the other account-operating revenues. Then based on the advice from KAP, reclassification was made to other income. The reclassification was carried out before closing the 2018 unaudited financial statements, namely, on 7 January 2019. Garuda, Citilink, and Sriwijaya had communicated regarding revenue recognition from Citilink and Mahata transactions with KAP before signing the agreement.

Discussions with KAP were conducted to avoid differences in perceptions of the transaction accounting records. Informal discussions do as much as two times before KAP is set to conduct an audit of Garuda's financial statements in the book 2018. The initial discussion with KAP using the example of similar transactions with business transactions at the provision of connectivity services. Discussions with KAP conducted using data / transaction-related documents work together with providers of connectivity services after signing the Public Accounting Services Agreement between Garuda with KAP No. IG / PERJ / DF-3690/2018 of 18 December. So that KAP participates in accounting records before the audit period and simultaneously audits Garuda. 
Due to discussions with Citilink and Sriwijaya to uniform the recognition of revenue for the transaction, Citilink and Sriwijaya will follow Garuda's revenue recognition. Managing Director and Chief Financial Sriwijaya Sriwijaya Sriwijaya states that the Financial Report 2018 unaudited did not record revenue on the transaction work together that because there are doubts to recognize and record it. Then KAP proposing adjusting the journal in March 2019 to identify and record the transaction work together, such as others' income. Besides, Sriwijaya's participation in the collaboration between Citilink and Mahata involved 11 PT NAM Air aircraft, of which PT NAM Air is a subsidiary of Sriwijaya.

The results confirm the CPC with the Director of Finance of PT NAM Air known that NAM Water does not recognize revenue over the 11 units of the plane on the Financial Report 2018. Management Citilink Citilink showed that the transaction work's accounting treatment together is similar to Garuda's accounting treatment.

Apart from the oddities in the form of KAP's participation in accounting records before the audit period and at the same time conducting an audit on Garuda, it turns out that KAP also does not have the competence to conduct audits in airlines. It is known that from the results of checking personnel supporting data and confirmation to KAP by Garuda's Internal Audit, it is concluded that:

1. KAP does not have sufficient audit experience in airline companies; and

2. There are not enough auditors with qualifications with expertise in airline auditing, some of whom do not even have experience working as auditors.

Management seems to insist that the consolidated financial statement audit be carried out by KAP Tanubrata Sutanto Fahmi Bambang \& Rekan, even though they do not have sufficient competence. The participation of KAP in recording revenue before the audit period and conducting an audit of the financial statements facilitated management's intention to recognize revenue from the agreement with PT Mahata Aero Teknologi.

\section{IV) Summary of non-conformities}

The three mistakes made by management are closely related. The agreement that is not following the provisions and without in-depth study makes the partners unable to carry out the contract because they do not have sufficient technical and financial capabilities. The inability to enforce the agreement makes the recognition of income inconsistent with the statement of financial accounting standards. Communication with the firm gives suggestions for the company to recognize income as other income strengthened the fraud committed indications because management has consulted about revenue recognition mechanism before the contract is signed. The act of appointing the relevant KAP as an auditor for financial statements even though it does not have sufficient competence to create a conflict of interest. Conflict of interest due to KAP's participation in the pre-audit records and conducting the audit smoothed management's intention to recognize the revenue. Cheating also clarified with management actions that do not follow the company's audit committee's opinion. For example, income compensation for the proper installation of equipment and connectivity services inflight entertainment and content management of the agreement with PT Mahata Aero Technology can not be recognized entirely in 2018 .

\section{CONCLUSION}

The actions of the management of PT Garuda Indonesia (Persero) Tbk in 2018 recognized other income in the form of compensation income. It was used to install connectivity and entertainment service equipment onboard, and content management from the agreement with PT Mahata Aero Teknologi in the consolidated financial report of PT Garuda Indonesia (Persero) Tbk 2018 is an act of fraud (fraud). The fraud 
committed is included in the fraudulent financial reporting type ( fraudulent financial reporting ) or commonly known as management fraud. Such action is included in fraudulent financial reporting because it is in the form of deliberate or negligent acts by taking actions that result in material misleading financial reports. The actions taken provide benefits for management by providing better performance realization and covering losses that have occurred. This action can be classified as a cookbook scheme, namely recognizing income before it can be identified. Fraud is driven by industrial pressures in the form of unfavorable industrial conditions and financial pressures. Companies try to book profits as much as possible to achieve the target set. Three institutions associated with the financial and capital markets, namely the Financial Services Authority, Center for Development of Professional Finance (First Aid) of the Ministry of Finance of the Republic of Indonesia, and the Audit Board of the Republic of Indonesia has set non-conforming revenue recognition has been done by PT Garuda Indonesia (Persero) Tbk on 12018 consolidated financial statements.

The mistakes made by PT Garuda Indonesia (Persero) Tbk are as follows: (a) Cooperation in the provision of connectivity and in-flight entertainment services with PT Mahata Aero Teknologi. Which does not comply with existing regulations, namely the Regulation of the Minister of BUMN Number Per-03 / MBU / 08/2017, as already amended by Regulation of the Minister of SOE No. Per-04 / MBU / 09/2017 on Guidelines for Cooperation SOE and the draft Civil Code in article 1320 governing the validity of a treaty and article 1335 that describes a condition. The agreement will not have legal force ; (b) The recognition of income does not follow the statement of financial accounting standards (PSAK) 23 concerning the payment. The transaction did not meet the criteria to be classified as income from royalties for such transactions that do not contain intellectual property in the form of royalties. It is possible since the economic benefits associated with the transaction will not flow to the entity due to Mahata does not have sufficient financial capacity. The amount of revenue can not be measured reliably because the agreement can be changed over time and does not meet the illustrative PSAK 23 paragraph 20. The contract can still be canceled; (c) Management's actions in communicating with the public accounting firm (KAP) Tanubrata Sutanto Fahmi Bambang \& Partners regarding revenue recognition from the agreement with PT Mahata Aero Teknologi give rise to an indication of a conflict of interest.

The three mistakes made were closely related. The agreement that was not following the provisions made the partners unable to carry out the deal because they did not have sufficient technical and financial capabilities. The inability to perform the contract makes the recognition of income inconsistent with financial accounting standards. Indications of interest conflicts strengthened the fraud committed symptoms because management has consulted about the revenue recognition mechanism before the contract is signed. The related accounting firm was appointed as an auditor of the financial statements. However, it does not have sufficient competence. The fraud was also clarified by management's actions that did not follow its audit committee's opinion. Compensation income for installation rights for in-flight connectivity and entertainment service equipment and content management from the agreement with PT Mahata Aero Teknologi could not be fully recognized in 2018.

\section{REFERENCE}

Amrizal. 2004. Fraud Prevention and Detection by Internal Auditors. Jakarta: Financial and Development Supervisory Agency of the Republic of Indonesia. 
Financial Services Authority. 2019. Press Release number SP 26 / DHMS / OJK / VI / 2019: Financial Services Authority Imposes Sanctions for PT Garuda Indonesia (Persero) Tbk.

Garuda Indonesia. 2019. Letter of PT Garuda Indonesia (Persero) Tbk number GARUDA / JKTDF / 205 23/2019 dated 20 August 2020 regarding the Response to the Request for Explanation of the IDX Surta No. S-04821 / BEI.PP2 / 08-2019. Retrieved 13 January 2020. https://www.idx.co.id/StaticData/NewsAndAnnouncement/ANNOUNCEMEN TSTOCK/From_EREP/201908/a5d06b3cbf_fdabc3601d.pdf

Garuda Indonesia. 2019. Incidental Public Expose of Garuda Indonesia Group Cooperation - Mahata Aero Teknologi. Retrieved 13 January 2020.

https://www.garuda-indonesia.com/content/dam/garuda/files/pdf/investorrelations/corporate-action/Materi_-_Public_Expose_Insidentil_-_2019.pdf

Garuda Indonesia. 2019. Information Disclosure to the Shareholders of PT Garuda Indonesia (Persero) Tbk. In connection with material transactions to comply with Bapepam and Lk Regulation No.Ix.E.2 concerning material transactions and changes in main business activities. IDX. Accessed 12 January 2020. https://www.idx.co.id/StaticData/NewsAndAnnouncement/ANNOUNCEMEN TSTOCK/From_EREP/201904/b6eef9376e_481c88c8c4.pdf

Garuda Indonesia. 2019. Incidental Public Expose of Garuda Indonesia Group Cooperation - Mahata Aero Teknologi. Retrieved 13 January 2020.

https://www.garuda-indonesia.com/content/dam/garuda/files/pdf/investorrelations/corporate-action/Materi___Public_Expose_Insidentil_-_2019.pdf

Herdiansyah, H., 2010. Qualitative Research Methodology for Social Sciences. Publisher Salemba Humanika.

IAI. 2018. Statement of Financial Accounting Standards Number 23 concerning Income. IAI Global. Jakarta.

Indonesia National Air Carriers Association. 2019. Indonesia National Air Carriers Association Annual Report 2018. INACA. Accessed on 10 May 2020.

https://inaca.or.id/wp-content/uploads/2020/01/AR-18-INACA-dummy-forprint-approval-14102019.pdf 8/7/20

Indonesia stock exchange. 2018. PT Garuda Indonesia Consolidated Financial Statements 2018. IDX. Accessed on 26 December 2019. http://www.idx.co.id

Indonesia stock exchange. 2018. Consolidated Financial Statements of PT Garuda Indonesia dated 30 September 2018. IDX. Retrieved 10 January 2020. http://www.idx.co.id

Indonesia stock exchange. 2018. Consolidated Financial Statement of PT Garuda Indonesia dated 31 Meret, 201 9. IDX. Retrieved 10 January 2020. http://www.idx.co.id

Indonesia stock exchange. 2018. PT Garuda Indonesia Annual Report 2018. IDX. Retrieved 10 January 2020. http://www.idx.co.id

Ministry of Finance. 2019. Press Release number SP - 33 / KLI / 2019: Minister of Finance Imposes Auditor Sanctions on Garuda Indonesia Financial Statements.

Romney, Marshall B., and Paul John Steinbart. 2015 . 13th edition of Accounting Information Systems Jakarta: Salemba Empat.

Supreme Audit Agency of the Republic of Indonesia. 2019. Report on the Results of Compliance Examination on Revenue Management 2018 at PT Garuda Indonesia (Persero) TBK, Subsidiaries, and Related Agencies in Jakarta and Banten. Accessed on 1 July 2020. https: // www. sir . g o.id 